\title{
Coated Surface on Ti-30Ta Alloy for Biomedical Application: Mechanical and in-vitro Characterization
}

\author{
Patricia Capellato * (D), Samira E. A. Camargo ${ }^{b}$, Gilbert Silva ${ }^{c}$, Daniela Sachs ${ }^{a}$, Filipe Bueno Vilela ${ }^{a}$, \\ Cecilia A. de C. Zavaglia ${ }^{,}$Ketul C. Popat, Ana P.R. Alves Clarof \\ ${ }^{a}$ Universidade Federal de Itajubá - UNIFEI, Instituto de Física e Química, Av. BPS, 1303, 37500-903, \\ Itajubá, MG, Brasil \\ ${ }^{b}$ University of Florida, College of Dentistry, Restorative Dental Sciences, Division of Prosthodontics, \\ Gainesville, FL 32608, USA \\ 'Universidade Federal de Itajubá - UNIFEI, Instituto de Engenharia Mecânica, Av. BPS, 1303, 37500- \\ 903, Itajubá, $M G$, Brasil \\ ${ }^{d}$ Universidade Estadual de Campinas - UNICAMP, Faculdade de Engenharia Mecânica, Rua \\ Mendeleyev, 200, 13083-860, Campinas, SP, Brasil \\ ${ }^{e}$ Colorado State University - CSU, Department of mechanical Engineering, School of Biomedical \\ Engineering, Fort Collins, 80523, CO, USA \\ ${ }^{f}$ Universidade Estadual Paulista - UNESP, Faculdade de Engenharia, Campus Guaratinguetá, Av. \\ Ariberto Pereira da Cunha, 333, Pedregulho, 12516-410, Guaratinguetá, SP, Brasil
}

Received: July 09, 2020; Revised: October 15, 2020; Accepted: October 20, 2020

\begin{abstract}
Several studies have been carried out to develop new materials for biomedical applications. Material surfaces that present biomimetic morphology like nanotubes or nanofibers that provides nanoscale architectures have been shown to alter cell/biomaterial interactions. The coated surface biomaterial with biocompatible polymers and nanotubes of $\mathrm{TiO}_{2}$ is an alternative to improve osseointegration. The anodization process was performed to obtain nanotubes of $\mathrm{TiO}_{2}$ covering the $\mathrm{Ti}-30 \mathrm{Ta}$ alloy surface and the electrospinning process has been used for producing polymer fibers. Characterization techniques such as scanning electron microscopy (SEM - FEG), X-ray diffraction analysis (X-rays), thermogravimetric analysis (TGA), Differential Scanning Calorimetry (DSC) and contact angle were used for samples analyses. Adult human adipose-derived stem cells (ADSCs) were used to investigate the cellular response and $S$. aureus antimicrobial activity on these coated surfaces. The results indicated that both surface modification treatment showed a favorable micro-environment for cells growth and proliferation such as adhesion, viability and morphology which is a desire property for an implant. In addition, the antimicrobial activity study presented both materials with similar growth of S. aureus. So, it can conclude nanotubes and nanofibers can be used at biomedical field and both present similar cell evaluation and antimicrobial activity results.
\end{abstract}

Keywords: Biocompatible polymers, Titanium alloy, $\mathrm{TiO}_{2}$ nanotube, Cell response, Nanofibers.

\section{Introduction}

The increase in the life expectancy of the population in recent years has led to the study of new materials for biomedical applications with properties that allow better performance in vivo. However, the greatest challenge in this field of scientific research are the morphological and functional reproduction of living tissues that have gone through thousands of years of evolutionary optimization that match material with function ${ }^{1}$.

Metallic Biomaterials are commonly applied to improve the structure or restore the function of hard tissues, and are used for artificial joints, artificial bones, synthetic plates, orthodontic appliances, screws and dental implants ${ }^{2}$.

*e-mail: pat_capellato@yahoo.com.br
The interaction between the tissue and the surface of the implant is a dynamic process. During the first few seconds of exposure of the implant to the body, water, free molecules, and dissolved ions surround the surface of the implant. The healing process begins with the change in the composition of the fluid and adsorption of proteins. Then, the cells adhere to the surface and depending on the proteins on the surface, the cells will respond. Over time, the cell types formed and their surface activity change, resulting in tissue integration or formation of a fibrous capsule which is an undesired response ${ }^{3}$.

Studies have been shown that cells in the human body are predisposed to interact with nanostructured surfaces such as nanostructure surfaces and nanoscale materials interact with some proteins more effectively than conventional materials ${ }^{4,5}$. 
Different surface modification techniques for metal biomaterials have been proposed in recent years seeking a better biological response after their implantation ${ }^{6}$. In recent years, studies have demonstrated the efficiency of using $\mathrm{TiO}_{2}$ nanotube-containing surfaces to increase cell proliferation. Also, previous studies Capellato et al. ${ }^{7}$ and Bayram et al. ${ }^{8}$ investigated the association of nanotubular surface and deposition of polymeric nanofibers by electrospinning and demonstrated that the group with nanotubes and polymeric nanofibers presented high cell adhesion and proliferation. In this study, it was concluded that the morphology of polymeric nanofibers successfully mimics the natural size and anisotropy of bone collagen fibers 9 .

In the field of materials development for biomedical applications the interest in nanofibers has increased since these fibers mimic the polymer matrix ${ }^{10}$.

In this paper, we combined two nano surface treatments to improve cell/biomaterial interactions. Also, the bulk properties were altered by fabrication a Ti alloy with $30 \%$ of tantalum that influences the elastic modulus ${ }^{11}$. Thus, here we have a new surface treatment to this alloy in order to improve cell interaction in biomedical fields.

From the above, this research will seek to associate the deposition of PCL polymer fibers with the methodology developed for the growth of $\mathrm{TiO}_{2}$ nanotubes on the surface of the experimental Ti-30Ta alloy for biomedical applications.

\section{Materials and Methods}

This work is divided in several steps. Figure 1 shows the methodology development in order to illustrate and elucidate how it was performed.

\subsection{Fabrication of Ti-30Ta alloy}

The Ti-30Ta alloy was fabricated by mixing high-purity sponge Titanium (Sigma-Aldrich) and a sheet of Tantalum (Sigma-Aldrich). These metals were combined using a melting process in a high purity argon atmosphere. The resulting ingots were homogenized in a vacuum at $1000^{\circ} \mathrm{C}$ for 24 hours in order to eliminate the as-cast microscopic chemical segregation and the residual stress caused by plastic deformation on the elastic modulus. The alloy was then cold-worked by a rotary swaging process (rotation speed $1000 \mathrm{rpm}$ ) using a CNC lathe ZIL (Centur 30S, ROMY, Brazil) and solubilized at $950{ }^{\circ} \mathrm{C}$ for 2 hours followed by water cooling. The bars were cut into discs of $10 \mathrm{~mm}$ in diameter and $3 \mathrm{~mm}$ in thickness ${ }^{4}$.

\subsection{Fabrication of nanotube on Ti-30Ta alloy}

The anodization process was performed using a dual electrode system with platinum (counter electrode) (Sigma) and the Ti-30Ta alloy (working electrode), fixed at a distance of $15 \mathrm{~mm}$ apart. The electrodes were then suspended in an electrolyte contained $0.2 \mathrm{M} \mathrm{NH}_{4} \mathrm{~F}$ and glycerol and the voltage applied was $30 \mathrm{~V}$ for 6 hours. The electrodes were connected to a power supply (Fisher Scientific FB300 Electrophoresis) and performed at $30 \mathrm{~V}$ during 6 hours. Following the anodization process, the Ti-30Ta alloy substrate was rinsed in isopropyl alcohol and dried by compressed air. All anodized substrates were further annealed in an oxygen ambient furnace at $530^{\circ} \mathrm{C}$, with a ramping rate of $5^{\circ} \mathrm{C} / \mathrm{min}$ for 1 hour ${ }^{5}$. Then, the samples were divided into two groups: Group 1 - Nanotubes of $\mathrm{TiO}_{2}$ and Group 2 - Nanotubes of $\mathrm{TiO}_{2}$ covered with PCL, and were stored in a dissector until further characterization.

\subsection{Electrospinning}

A concentration of $13.6 \% \mathrm{w} / \mathrm{v}$ PCL solution was prepared by solubilizing Poly ( $\varepsilon$-caprolactone) with an average molecular weight of 70,000-90,000 g/mol (Sigma-Aldrich) with $3 \mathrm{~mm}$ pellets in a solvent mixture at a ratio of 1:1 formed by chloroform (Merck) and acetone (99.5\% Synth) under magnetic stirring at $40^{\circ} \mathrm{C}$ for 24 hours. The PCL solution was placed in a $20 \mathrm{~mL}$ plastic syringe (BD Plastipak) with needle inner diameter of $1.0 \mathrm{~mm}$. The discs of samples were fixed on aluminum foil which was used to collect electrospun fibers. The distance between the emitter and stationary collector was $12 \mathrm{~cm}$ from the collector to needle. Solutions were electrospun at $7 \mathrm{kV}$ of positive voltage with a solution flow rate of $6 \mathrm{~mL} / \mathrm{h}$ using a syringe pump ${ }^{12}$.

\subsection{Characterization of samples}

The surface topography of Group 1 - Nanotubes of $\mathrm{TiO}_{2}$ and Group 2 - Nanotubes of $\mathrm{TiO}_{2}$ covered with PCL was characterized by scanning electron microscopy (SEM)

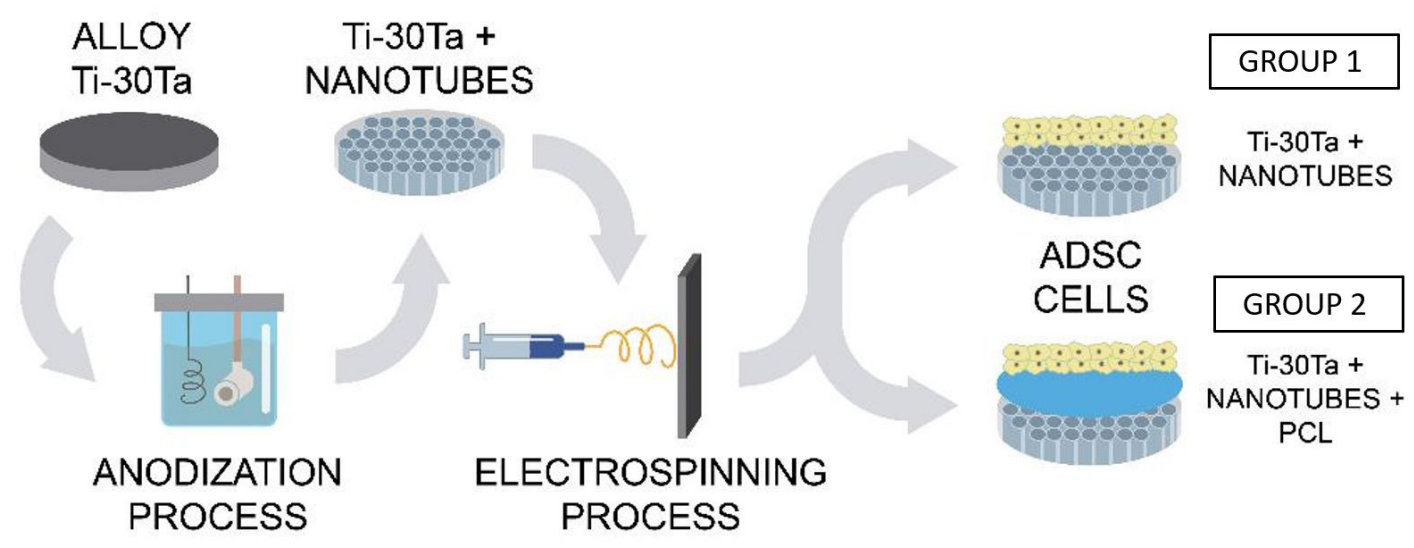

Figure 1. Methodology development. 
imaging (JEOL JSM 6100) with 10mm WD and 15keV. Prior to imaging, all substrates were coated with a $15 \mathrm{~nm}$ layer of gold. The wettability of the substrate surfaces was investigated using a sessile drop method $(2 \mathrm{ml})$ with a contact angle goniometer (Kruss DSA 10), equipped with video capture. The resulting images at the water-substrate interface were fit using the circle fitting profile. X-ray diffraction analysis were used to evaluate the crystallinity of the samples), using a X'Pert Philips PMD with a Panalytical X'celerator detector (using a $\mathrm{CuK} \alpha$ radiation).

\subsection{Characterization of PCL electrospun fibers}

Thermal analyses were performed on PCL fibers in order to evaluate the influence of electrospinning process on the polymer. Differential Scanning Calorimetry (DSC) analysis was accomplished on PCL fibers using a DSC 6220 (Nanotechnology -Seiko, model 6220). Samples of approximately $10 \mathrm{mg}$ in weight were encapsulated in aluminum pans, heated from $-75^{\circ} \mathrm{C}$ to $100^{\circ} \mathrm{C}$ with a scan rate of $20^{\circ} \mathrm{C} / \mathrm{min}$ under a nitrogen atmosphere and kept at $100^{\circ} \mathrm{C}$ for five minutes and quickly cooled to $-75^{\circ} \mathrm{C}$. A second heating scan was conducted with the same conditions. The melting temperature and glass transition $(\mathrm{Tg})$ were measured to determine the percentage of crystallinity (\%). The resulting thermograms were analyzed using the Muse Measurement-6.2U Software to determine the percentage of crystallinity (Xc \%) following Equation 1:

$$
(\%) \text { bulk crystallinity }=(\Delta H m) /\left(\Delta H m^{*}\right) \times 100
$$

where $\Delta \mathrm{Hm}$ is the enthalpy of melting of PCL $(\mathrm{J} / \mathrm{g})$ and $\Delta \mathrm{Hm}^{*}$ is the enthalpy of fully crystalline PCL (136 J/g). Thermogravimetric analysis (TGA) was carried out under nitrogen gas $(100 \mathrm{ml} / \mathrm{min})$ using a thermogravimetric analyzer (SII Nanotechnology equipment, model 6000) instrument. Fibers $(10.3 \mathrm{mg})$ were heated from room temperature to $1000^{\circ} \mathrm{C}$ at $10^{\circ} \mathrm{C} / \mathrm{min}$.

\subsection{In-vitro evaluation}

\subsubsection{Cell biocompatibility}

Adult human adipose-derived stem cells (ADSC, Colorado State University, CO, USA) were used in this study. ADSC cells were cultured at $37^{\circ} \mathrm{C}$ in a $5 \% \mathrm{CO}_{2}$ atmosphere in surface area $175 \mathrm{~cm}^{2}$ polystyrene vented tissue-culture flasks. The cell growth media consisted of Dulbecco's Modified Eagle Medium (DMEM) with 10\% fetal bovine serum and $1 \%$ penicillin/streptomycin. Cells of passage 3 were used for subsequent studies. Prior to seeding the cells, the samples were incubated in PBS for 30 mins followed by 3 rinses in PBS and 30 mins of UV exposure. The cells were seeded onto samples at a concentration of 6,000 cells/well in 48 well plates and were cultured at $37^{\circ} \mathrm{C}$ in a $5 \% \mathrm{CO}_{2}$.

\subsubsection{Adhesion and proliferation}

The ADSC cell response was investigated after 1 and 7 days of culture in growth media. Cell adhesion and proliferation were evaluated by staining the cells with 5-chloromethylfluorescein diacetate (CMFDA, Life Technologies), rhodamine phalloidin, and 4', 6-diamidino2-phenylindole (DAPI, Invitrogen) to visualize cytoplasm, cytoskeleton, and nucleus respectively using a fluorescence microscope (Zeiss). Prior to staining unadhered cells were aspirated and the substrates were gently rinsed 2 times with PBS before being transferred to a new 48- well plate. The substrates were then incubated at $37^{\circ} \mathrm{C}$ in $5 \% \mathrm{CO}_{2}$ in a $10 \mu \mathrm{M}$ solution of CMFDA in PBS for 45 mins.

Following this incubation, the solution was aspirated and the substrates were incubated in growth media at $37^{\circ} \mathrm{C}$ in $5 \% \mathrm{CO}_{2}$ for $30 \mathrm{mins}$. The media was then aspirated and the substrates were rinsed once in PBS before being transferred to a new 48- well plate where the cells were fixed in a $3.7 \%$ $\mathrm{w} / \mathrm{v}$ formaldehyde solution in DI water for $15 \mathrm{mins}$ at RT. The fixative was then aspirated and the substrates were rinsed 3 times in PBS for 5 mins per rinse before being transferred to a new 48-well plate. The cells were permeabilized in a $1 \% \mathrm{v} / \mathrm{v}$ Triton-X solution in water for $3 \mathrm{mins}$ at RT. Then, was aspirated and the substrates were rinsed and transferred to a new 48 well plate where they were incubated at $37^{\circ} \mathrm{C}$ in $5 \% \mathrm{CO}_{2}$ in a $5 \mu \mathrm{L} / \mathrm{mL}$ rhodamine-phalloidin solution in DI water for 25 mins at RT before DAPI was added to the solution at a concentration of $1 \mu \mathrm{L} / \mathrm{mL}$ and were incubated for additional $5 \mathrm{mins}$. The solution was then aspirated and the substrates were rinsed 2 times in PBS before being stored in PBS in a light resistant container at $20^{\circ} \mathrm{C}$ until imaging. Analysis of the fluorescence images was performed with ImageJ software.

\subsubsection{Cell viability}

Cell viability was determined by a Cell Titer-Blue Cell Viability Assay (Promega G808A, Madison, WI), which was used according to the manufacturer's instructions. After 1, 4 and 7 days, $50 \mu \mathrm{L}$ of Cell Titer-Blue dye was added to samples $(n=5)$ for every $500 \mu \mathrm{L}$ of culture media and samples were incubated for $4 \mathrm{~h}$ at $37^{\circ} \mathrm{C}$ and $5 \% \mathrm{CO}_{2}$. Sample fluorescence was read in a microplate reader (Molecular Devices Spectra Max M3, Sunnyvale, CA) at $570 \mathrm{~nm}$ and 600nm.

\subsubsection{Cell morphology}

ADSC cells were plated on the samples of Group 1 - Nanotubes of $\mathrm{TiO}_{2}$ and Group 2 - Nanotubes of $\mathrm{TiO}_{2}$ covered with PCL, which were placed in 48- well plates. The cultures were maintained in Dulbecco's Modified Eagle Medium (DMEM, Gibco-Life Technologies, NY, USA) supplemented with $10 \%$ fetal bovine serum (FBS, Gibco), penicillin (100 U/ mL) (Gibco) and streptomycin $(100 \mathrm{mg} / \mathrm{mL})(\mathrm{Gibco})$ at $37^{\circ} \mathrm{C}$ for 1 and 7 days in a humidified atmosphere with $5 \% \mathrm{CO}_{2}$.

Then, the cells adhered to the samples were fixed in a solution of $3 \%$ glutaraldehyde, $0.1 \mathrm{M}$ sodium cacodylate, and $0.1 \mathrm{M}$ sucrose for $45 \mathrm{~min}$. Samples were then soaked for $10 \mathrm{~min}$ in a buffer solution of $0.1 \mathrm{M}$ sodium cacodylate and $0.1 \mathrm{M}$ sucrose. Samples surface and cells were processed in serial ethanol dehydrations for $10 \mathrm{~min}$ each and dehydrated in hexamethyldisilazane before being stored in a desiccator until SEM imaging. The samples were sputter-coated with palladium-gold alloy (Polaron SC 7620 Sputter Coater, Quorum Technologies, Newhaven, UK) at a thickness of $10 \mathrm{~nm}$ (10-15 mA, under a vacuum of 130 mTorr). After, the SEM was operated at $15 \mathrm{kV}$, spot 3 to 6 (JEOL). 


\subsubsection{Antimicrobial activity}

The bacterial proliferation analysis was performed according to the methodology proposed by Pereira (2011) using the reference strains [American Type Culture Collection (ATCC)], S. aureus (ATCC 6538). The strains were seeded in agar brain heart infusion (BHI) and incubated at $37^{\circ} \mathrm{C}$ for 24 hours. After colonies of microorganisms was suspended in sterile physiological solution [0.9\% sodium chloride $(\mathrm{NaCl})]$ and adjusted to a 0.5 -turbidity on the MacFarland scale (1,5 $\times$ $10^{8} \mathrm{UFC} / \mathrm{mL}$ ). The samples were placed in 24- well plates with $2 \mathrm{~mL}$ of BHI broth supplemented with $5 \%$ sucrose and inoculated with $0,1 \mathrm{~mL}$ of the bacterial suspension. The samples were incubated at $37^{\circ} \mathrm{C}$ for 48 hours, and the media was changed after 24 hours.

After that period, the samples were washed aseptically with $2 \mathrm{~mL}$ of in sterile physiological solution and placed in tubes with $10 \mathrm{~mL}$ of in sterile physiological solution and sonicated for 30 seconds to dispersive the biofilms. The suspension was considered to have a dilution factor of 10-1 and was diluted with the addition of in sterile physiological solution to $10^{-8}$. Aliquots of $0,1 \mathrm{~mL}$ were seeded on BHI agar plates and incubated for 24 hours at $37^{\circ} \mathrm{C}$. The number of colonies was counted, calculated in $\mathrm{CFU} / \mathrm{mL}$ and transformed in $\log 10(20,35,40,43,44)$.

\subsection{Statistical analysis}

Each experiment was reconfirmed on at least three different substrates from $\left(n_{\min }=3\right)$. All the quantitative results were analyzed using an analysis of variance (ANOVA). Statistical significance was considered at $p<0.05$. During the analysis, variances among each group were not assumed to be equal and a two-sample t-test approach was used to test the significance between the Group 1 - Nanotubes of $\mathrm{TiO}_{2}$ and Group 2 - Nanotubes of $\mathrm{TiO}_{2}$ covered with PCL. This analysis was conducted using the Microsoft Office Excel data analysis software.

\section{Results and Discussion}

Implantable biomedical devices often promote fibrous tissue encapsulation on the material-tissue interface. These adverse tissue responses are a critical consideration for the success and optimal integration of long-term implants ${ }^{13-15}$. Material surfaces that present biomimetic morphology like nanotube and nanofibers that provides nanoscale architectures have been shown to alter cell/biomaterial interactions ${ }^{16}$. Thus, in this study we investigated the association of two nano surface treatment to improve cell interaction on biomedical fields.

SEM images (See Figure 2a) shows the self-ordered formation of nanotubular oxide layers on Ti-30Ta alloy. The anodization process was carried out in an electrolyte solution containing $0.2 \mathrm{M} \mathrm{NH} 4 \mathrm{~F}$ and glycerol at $30 \mathrm{~V}$ for 6 hours and annealed in furnace at $530^{\circ} \mathrm{C}\left(5^{\circ} \mathrm{C} / \mathrm{min}\right)$ for 1 hour. The $\mathrm{TiO}_{2}$ nanotubes covered all surface and have an average diameter of $80-100 \mathrm{~nm}$ and a nanotube length of $1 \mu \mathrm{m}$. The results in this study are in accordance with our previous

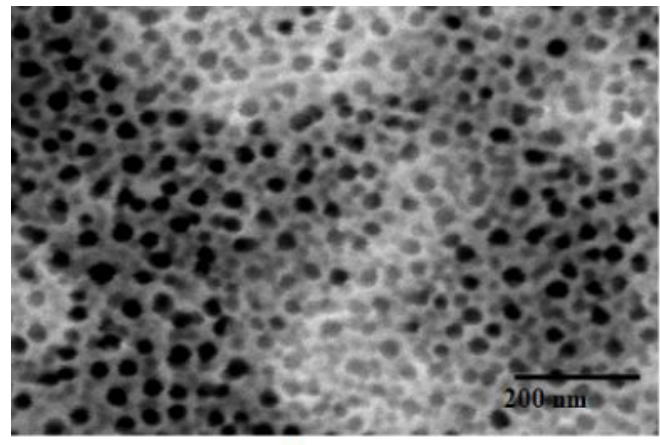

(a)

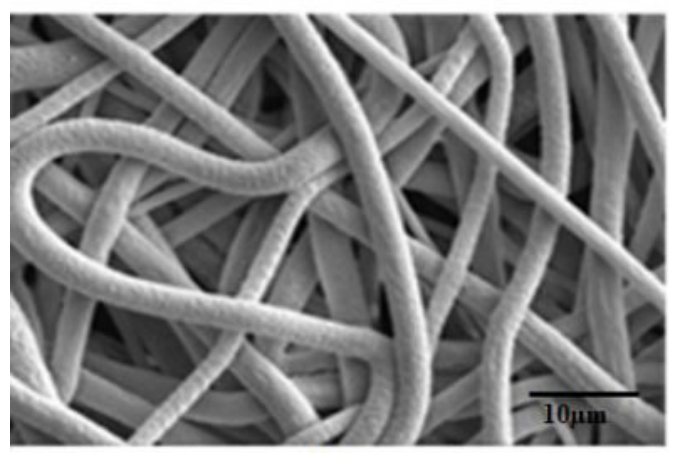

(c)

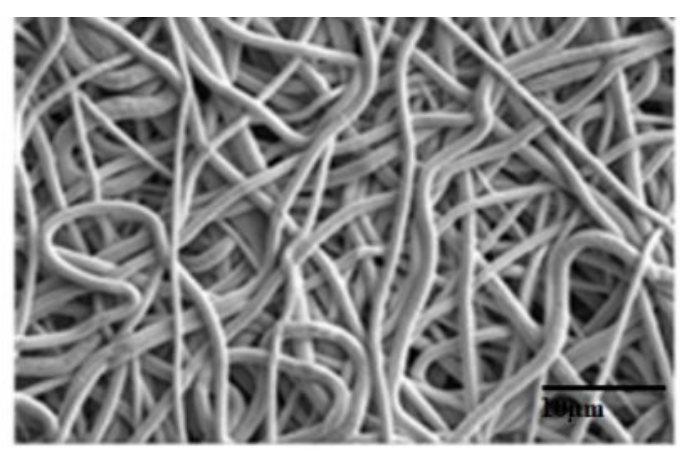

(b)

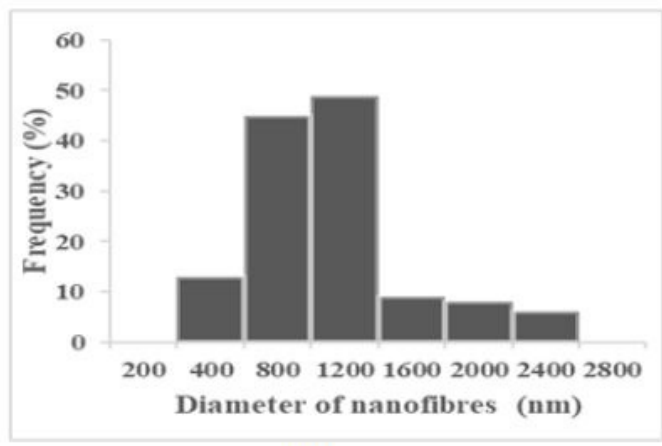

(d)

Figure 2. SEM micrograph images of the (a) Group 1 - Nanotubes of $\mathrm{TiO}_{2}$, (b) and (c) Group 2 - Nanotubes of $\mathrm{TiO}_{2}$ covered with PCL and (d) bar graph with fibers diameter. 
studies that investigated the influence of voltage and time in the anodization process to the formation of nanotube ${ }^{17}$.

Figure $2 b$ and $c$ shows the surface after electrospinning at two different magnification all the surfaces were covered by nanofibers. Figure $2 \mathrm{~d}$ shows the diameters of the nanofibers that were estimated to be in the range of $400 \mathrm{~nm}$ to $2400 \mathrm{~nm}$ with mean value of $1000 \mathrm{~nm}$. Souza ,2018 obtained similar results. There is a direct link between higher mean diameters of electrospun fibers and polymer solutions with higher concentrations. Fibers processed by electrospinning typically have a unimodal distribution while bimodal fibers have been observed in droplets formed by the similar process of electro spraying (LIN) $)^{8,12,18-22}$.

Bimodal fibers consisting of alternating micro and nanofibers were observed in studies with Poly(ethyleneoxide) (PEO)/water system at concentrations of $8 \mathrm{wt} \%$ and higher. Parameters such as electrospinning voltage, feed rate of the polymer solution, and the properties of the solution such as concentration present high influenced on shape of fibers. In this study was obtained this unusual formation of fibers with two diameter sizes: primary and secondary ${ }^{18,22}$.

Figure 3 shows the formation of anatase a peak around $25^{\circ}$ with the exception of the Ti-30Ta alloy without surface coating. The anatase phase enhances the cellular response required in biomedical applications ${ }^{17,23-25}$. Also, the main characteristic diffraction peaks for crystalline PCL $\left(2 \theta=19.2^{\circ}\right)$.

The surface charge of a biomaterial is an important property in an implantable device. This trait translates into the hydrophilicity or relative wettability of a material, and plays a key role in directing cell-material interaction. In biomedical applications, lower hydrophilicity or increased hydrophobicity is required for improved cellular interaction. Previous studies have related the surface energy of a biomaterial with cellular functionality such as protein adsorption, platelet adhesion and activation leading to blood coagulation, and bacterial adhesion $^{17,26-30}$.Thus, in this study, the hydrophilic behavior of Group 1 - Nanotubes of $\mathrm{TiO}_{2}$ and Group 2 - Nanotubes of $\mathrm{TiO}_{2}$ covered with PCL were investigated by measuring their respective contact angles (See Figure 4).

The DSC analysis was used to evaluated the crystallinity of the electropsun fibers. Crystallinity can influence cell anchorage, and polymer degradation ${ }^{31,32}$. According to literature, crystallinity can be influenced by the parameters of the electrospinning process such as dissolution of the polymer, distance between jet and collector, rapid solidification of the fibers during electrospinning, and the diameter of the fibers ${ }^{33-35}$. The thermal properties of the polymer were analyzed using thermogravimetry (TGA/DTA) and differential scanning calorimetry (DSC) techniques. The TGA / DTA (Figure 5) presented two mass variations. The first, there is a temperature below $100{ }^{\circ} \mathrm{C}$, is related to the loss of water or some solvent used in the processing of the solution. The second was a more intense variation, with loss of about $91.7 \%$ mass. Degradation begins at $325^{\circ} \mathrm{C}$, within the range expected in the literature. Starting at $700^{\circ} \mathrm{C}$, a residual mass of $6.2 \%$ is observed.

The first heating (Figure 6a) in the DSC shows a single endothermic peak regarding PCL melting, the melting temperature was $59^{\circ} \mathrm{C}$ and enthalpy of $66.52 \mathrm{~J} / \mathrm{g}$. During cooling (Figure $6 \mathrm{c}$ ) the curve showed an exothermic peak with maximum rate at $29^{\circ} \mathrm{C}$ and enthalpy of $51.42 \mathrm{~J} / \mathrm{g}$, related to the crystallization of the polymer. During the second heating (Figure 6b) it was possible to observe a change of baseline at $-2.5^{\circ} \mathrm{C}$, this type of variation is related to glass transition, but in the literature it is much lower values, around $-60^{\circ} \mathrm{C}$.

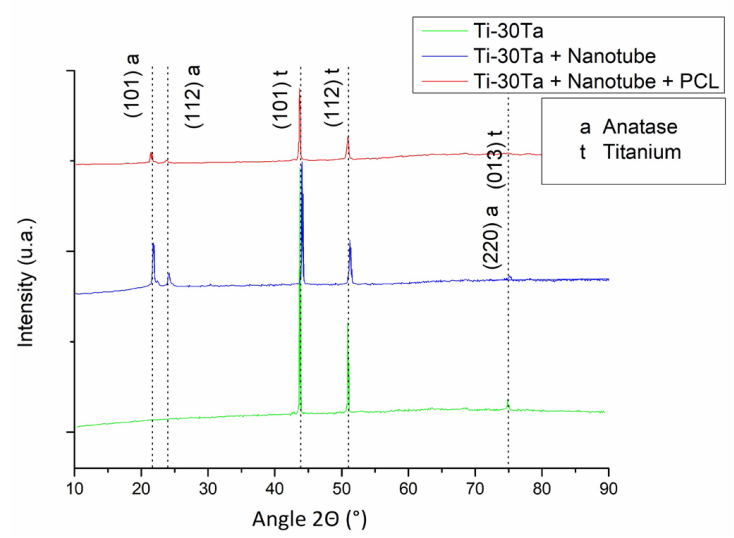

Figure 3. X-ray diffraction analysis (XRD) of Group 1 - Nanotubes of $\mathrm{TiO}_{2}$, and Group 2 - Nanotubes of $\mathrm{TiO}_{2}$ covered with PCL.

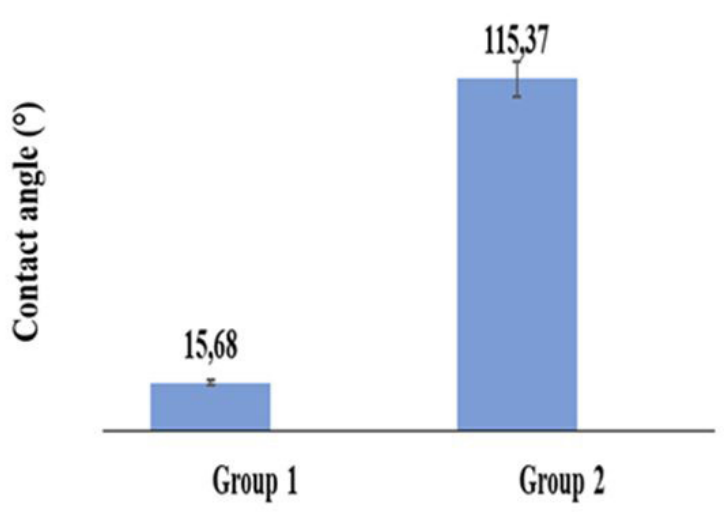

Figure 4. Results of contact angle measurements of Group 1 Nanotubes of $\mathrm{TiO}_{2}$, and Group 2 - Nanotubes of $\mathrm{TiO}_{2}$ covered with PCL.

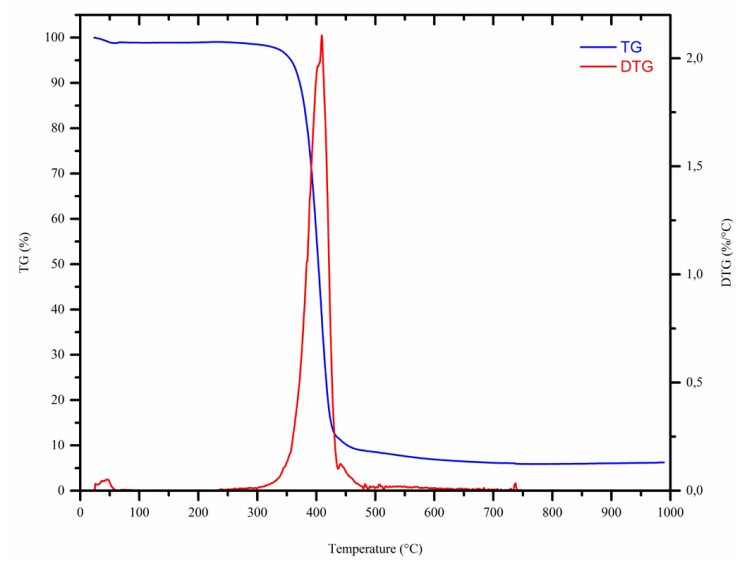

Figure 5. TG/DTG analysis of fiber after electrospinning deposition on Group 2 - Nanotubes of $\mathrm{TiO}_{2}$ covered with PCL. 

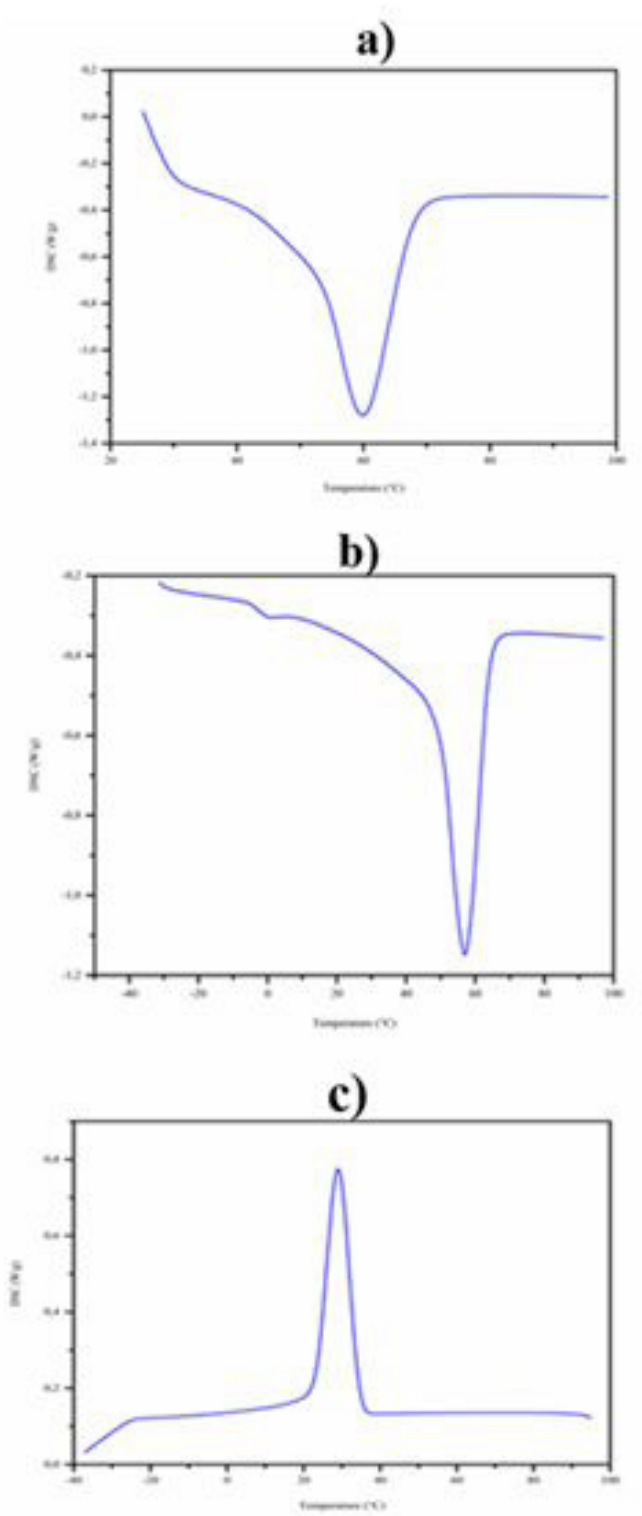

Figure 6. a) First heating, b) Second heating and c) During cooling the curve showed an exothermic peak with maximum rate at $29^{\circ} \mathrm{C}$ and enthalpy of $51.42 \mathrm{~J} / \mathrm{g}$.CL. still during second heating the formation of an endothermic peak occurs, at $57^{\circ} \mathrm{C}$, related to PCL fusion, and enthalpy of $62.35 \mathrm{~J} / \mathrm{g}$. The absence of other peaks suggests that the solvents used in the preparation of the solution evaporated during the electrolysis of PCL. An important factor for the application of these fibers to biomaterials, since these solvents are toxic to the body. The lower melting temperature and enthalpy found during the second heating indicate a higher degree of crystallinity in the polymer when in the fiber format, according to the literature the electrochemical processing induces a higher molecular orientation, increasing the degree of crystallinity of the material ${ }^{35}$.

In the investigation of adhesion and proliferation the results of cell counts indicate that Group 1 - Nanotubes of $\mathrm{TiO}_{2}$ presented a significant effect on the number of cells present, showing an increase of cells from day 1 to day 7 culture period $(\mathrm{p}=0.0005)$. Also, it was observed a slight increase of cell proliferation by Group 2 - Nanotubes of $\mathrm{TiO}_{2}$ covered with PCL after 7 days $(\mathrm{p}=0.0169)$ (Figure 7). After 1 day, there was no significance cell proliferation between Group 1 - Nanotubes of $\mathrm{TiO}_{2}$ and Group 2 Nanotubes of $\mathrm{TiO}_{2}$ covered with PCL $(\mathrm{p}=0.0560)$. However, the Group 1 presented higher cell proliferation than Group 2 - Nanotubes of $\mathrm{TiO}_{2}$ at day $7(\mathrm{p}=0.0203)$ (Figure 7).

According to our results, the Group 1 - Nanotubes of $\mathrm{TiO}_{2}$ and Group 2 - Nanotubes of $\mathrm{TiO}_{2}$ covered with PCL promoted high cell proliferation at day 7 which can be related to a good interaction between the cells and the material. Also, Manam et al. ${ }^{36}$ pointed out the synergistic interplay between the $\mathrm{TiO}_{2}$ crystal structure and spin-coated PCL film in facilitating L929 cell interactions with the scaffold surface.

Fluorescence microscopy images revealed that Group 1 - Nanotubes of $\mathrm{TiO}_{2} 1$ and Group 2 - Nanotubes of $\mathrm{TiO}_{2}$ covered with PCL were all able to support cell adhesion and proliferation for up to 7 days of culture (Figure 8 and 9).

Cell viability was performed the Cell Titer-Blue cell viability assay revealed that cells proliferated and remained viable on Group 1 - Nanotubes of $\mathrm{TiO}_{2}$ and Group 2 Nanotubes of $\mathrm{TiO}_{2}$ covered with PCL for up to 7 days of culture (Figure 10). For Group 1 - Nanotubes of $\mathrm{TiO}_{2}$, it was observed an increase of cell viability for up to 7 days of culture, showing a significant difference only between day one and day $4(p=0.0005)$. After 1,4 and 7 days, it was

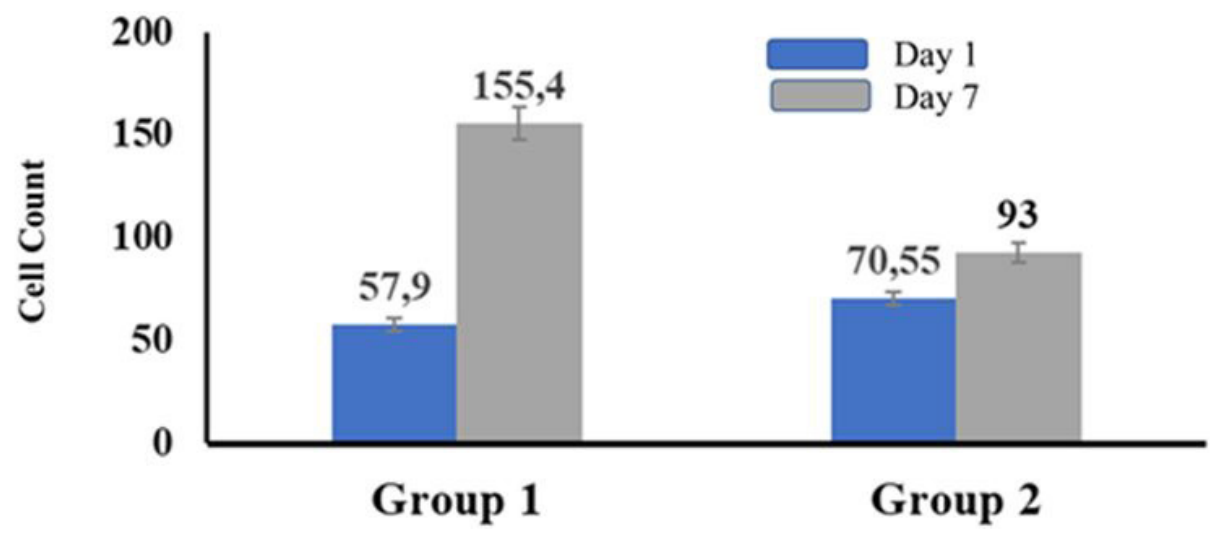

Figure 7. Quantification of proliferation on Group 1 - Nanotubes of $\mathrm{TiO}_{2}$ and Group 2 - Nanotubes of $\mathrm{TiO}_{2}$ covered with PCL after 1 and 7 days of culture. ${ }^{*}$ Indicates significant difference $(\mathrm{p}<0.05)$. 


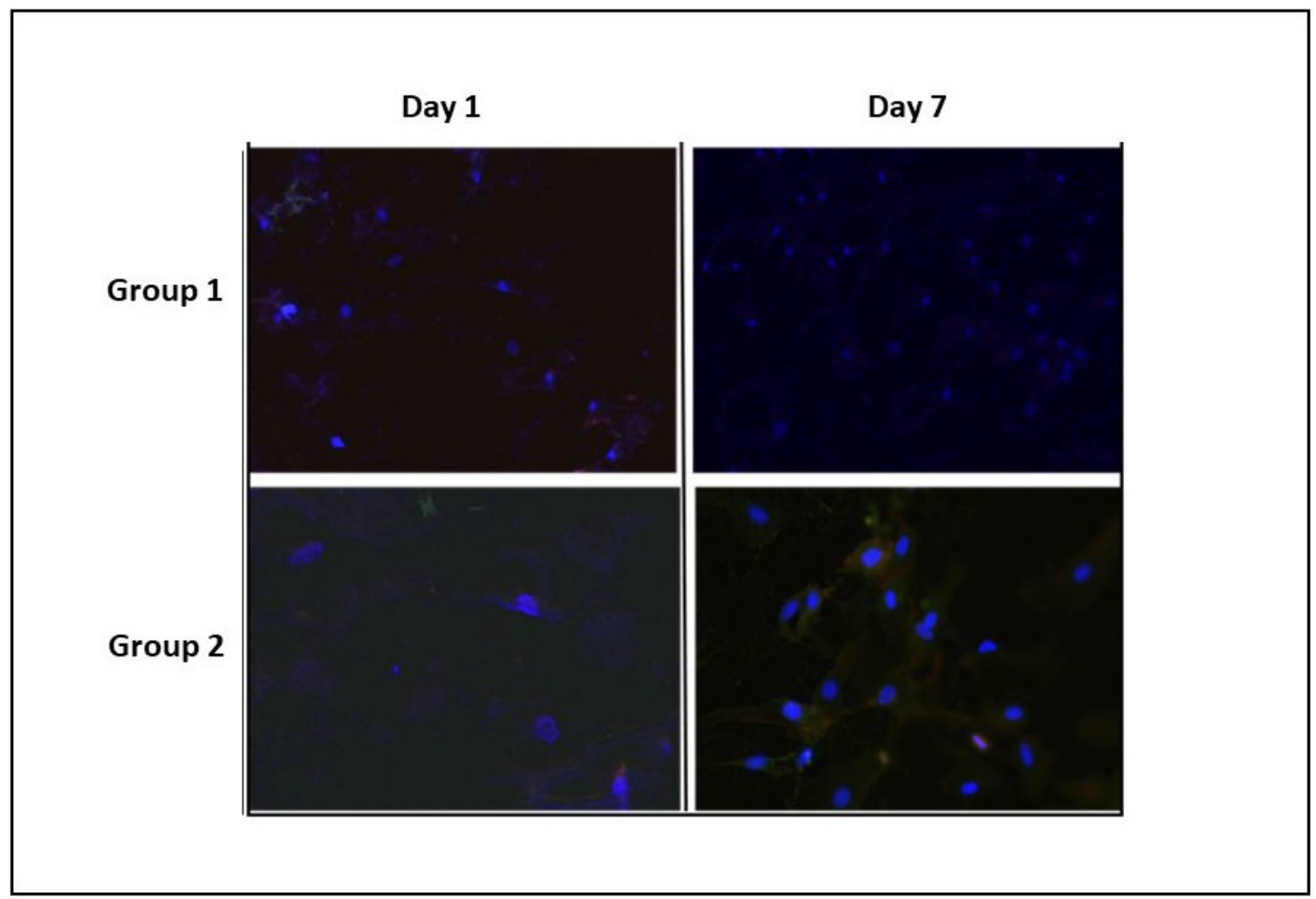

Figure 8. Representative fluorescent images of cells on Group 1 - Nanotubes of $\mathrm{TiO}_{2}$ and Group 2 - Nanotubes of $\mathrm{TiO}_{2}$ covered with PCL after 1 and 7 days of culture.

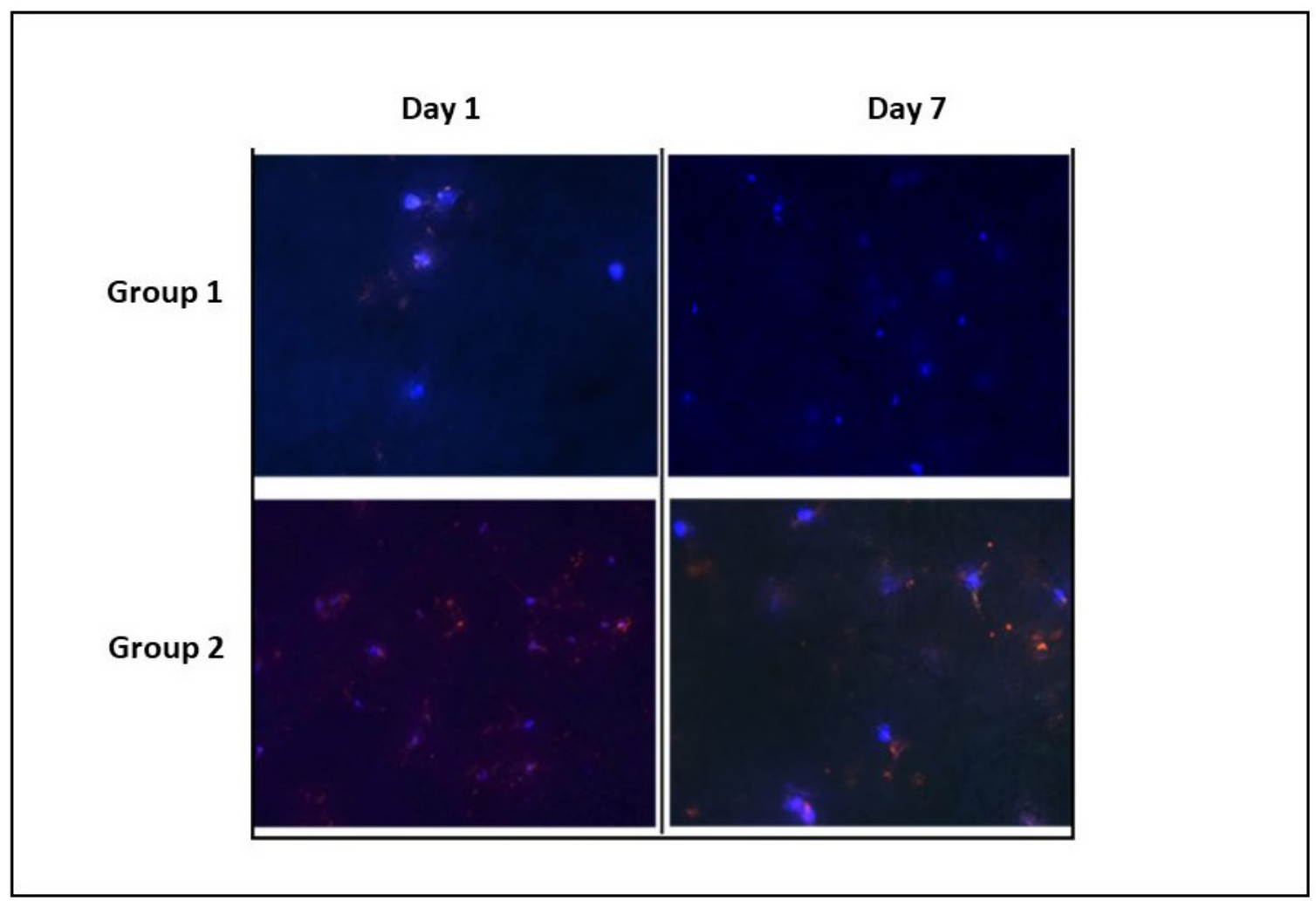

Figure 9. Representative fluorescent images of cells on Group 1 - Nanotubes of $\mathrm{TiO}_{2}$ and Group 2 - Nanotubes of $\mathrm{TiO}_{2}$ covered with PCL after 1 and 7 days of culture. 
not found statistically significant difference for Group 2 Nanotubes of $\mathrm{TiO}_{2}$ covered with PCL samples. There was no difference in cell viability between Group 1 - Nanotubes of $\mathrm{TiO}_{2}$ and Group 2 - Nanotubes of $\mathrm{TiO}_{2}$ covered with PCL, independent of days of culture ( $p>0.005)$ (Figure 10). Both materials showed a favorable micro-environment for cells growth and proliferation which is a desire property for an implant.

Cell morphology was investigated by SEM shows the interaction of cell extensions with the Group 1 - Nanotubes of $\mathrm{TiO}_{2}$ and Group 2 - Nanotubes of $\mathrm{TiO}_{2}$ covered with PCL.

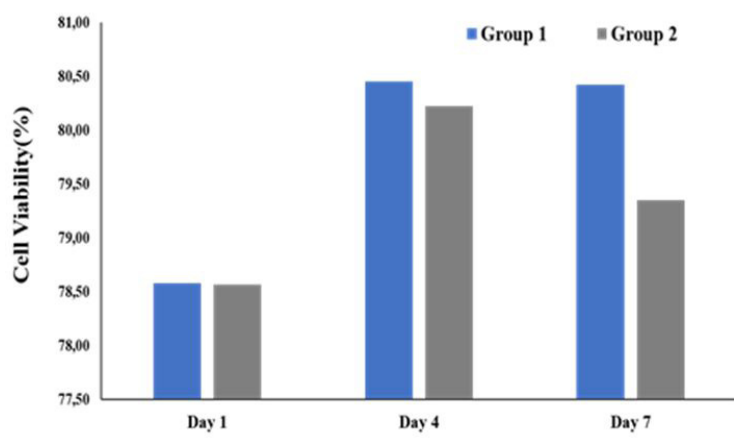

Figure 10. Cell viability of Group 1 - Nanotubes of $\mathrm{TiO}_{2}$ and Group 2 - Nanotubes of $\mathrm{TiO}_{2}$ covered with PCL after 1, 4 and 7 days of culture. *Indicates significant difference $(\mathrm{p}<0.05)$.
SEM results demonstrated that cells adhered and proliferated on these materials after 7 days in culture and cells were distributed on the surfaces (Figure 11 and 12).

The biocompatibility of the materials can be evaluated by the direct interaction between its surface and the cells. In this way, we can affirm that Group 1 - Nanotubes of $\mathrm{TiO}_{2}$ and Group 2 - Nanotubes of $\mathrm{TiO}_{2}$ covered with PCL are biocompatible.

Antimicrobial activity study with scanning electron microscopy (SEM) was used to illustrate biofilms formed on the Group 1 - Nanotubes of $\mathrm{TiO}_{2}$ and Group 2 - Nanotubes of $\mathrm{TiO}_{2}$ covered with PCL. The discs were fixed for $1 \mathrm{~h}$ in $2.0 \%$ glutaraldehyde and dehydrated in several ethanol washes $(10,25,50,75$, and $90 \%$ for $20 \mathrm{~min}$ and $100 \%$ for $1 \mathrm{~h})$. The samples were dried overnight in a bacteriological incubator at $37^{\circ} \mathrm{C}$, and afterwards they were mounted on aluminum stubs, with copper tape, coated with gold in a low-pressure atmosphere with an ion sputter coater. The surface topographies of the biofilms were visualized and photographed using a scanning electron microscope (Carl Zeiss ${ }^{\circledR}$ Evo MA 15).

Figure 13 and 14 showed both materials with similar growth of S. aureus. Also, the data are presented as mean \pm SEM and the statistical significance was analyzed by analyses of variance (ANOVA), followed by Newman-Keuls post hoc analysis. Results with $\mathrm{P}<0.05$ were considered statistically significant. These results are in accordance with the literature. In addition, the antimicrobial surface is desirable properties of biomaterials for biomedical application ${ }^{37-47}$.

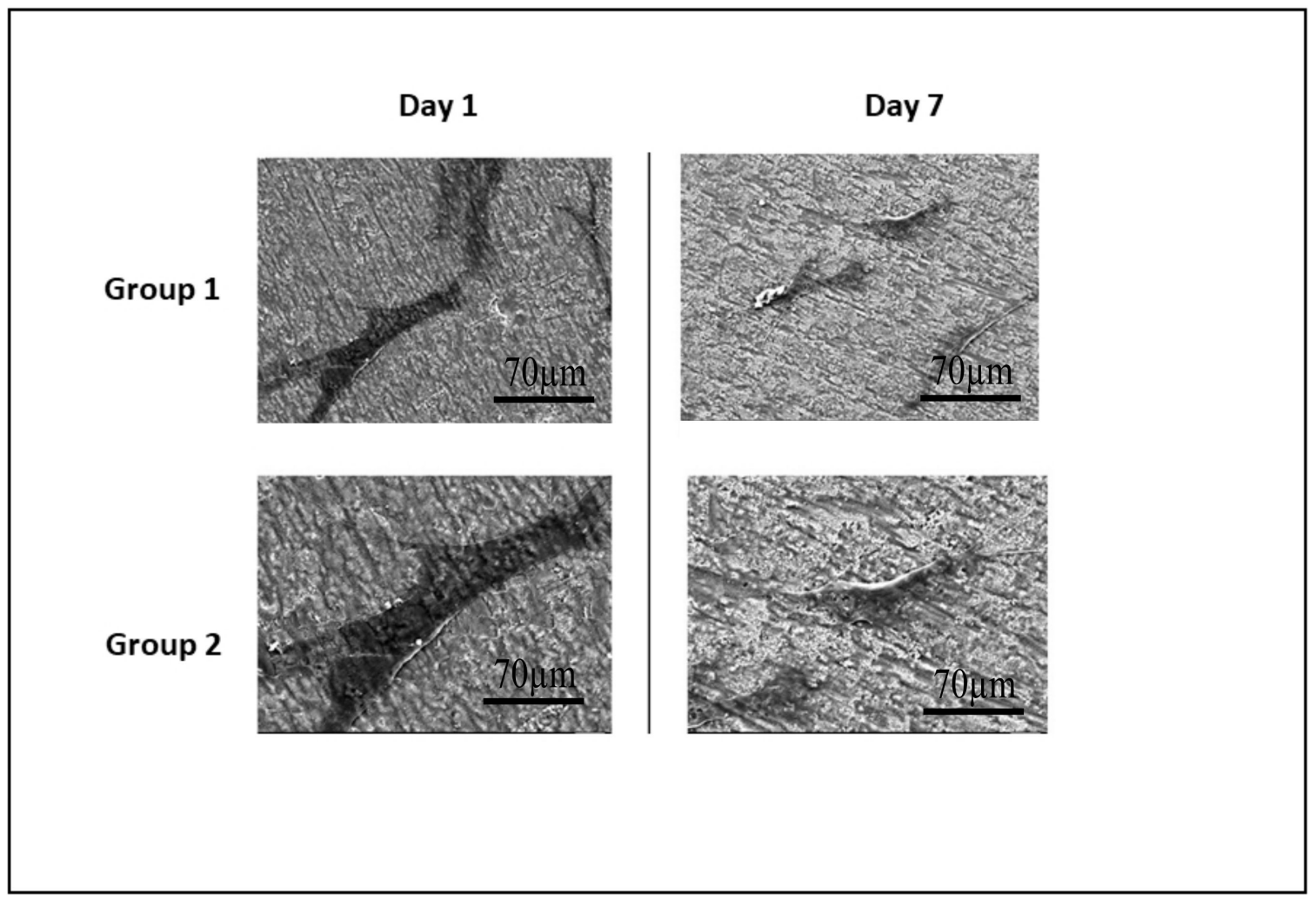

Figure 11. Representative SEM images of cells on Group 1 - Nanotubes of $\mathrm{TiO}_{2}$ and Group 2 - Nanotubes of TiO ${ }_{2}$ covered with PCL after 1 and 7 days of culture. 


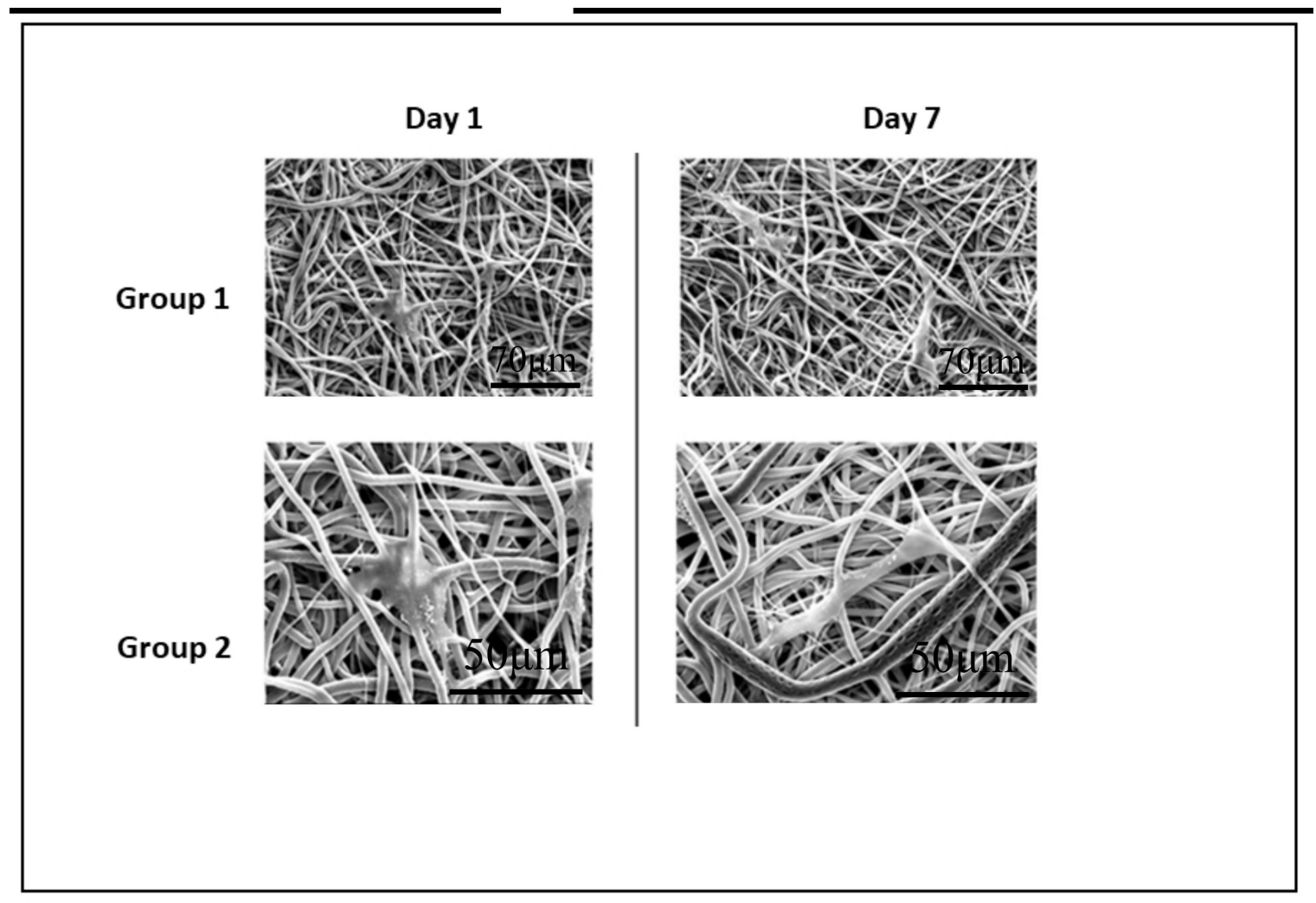

Figure 12. Representative SEM images of cells on Group 1 - Nanotubes of $\mathrm{TiO}_{2}$ and Group 2 - Nanotubes of $\mathrm{TiO}_{2}$ covered with PCL after 1 and 7 days of culture.

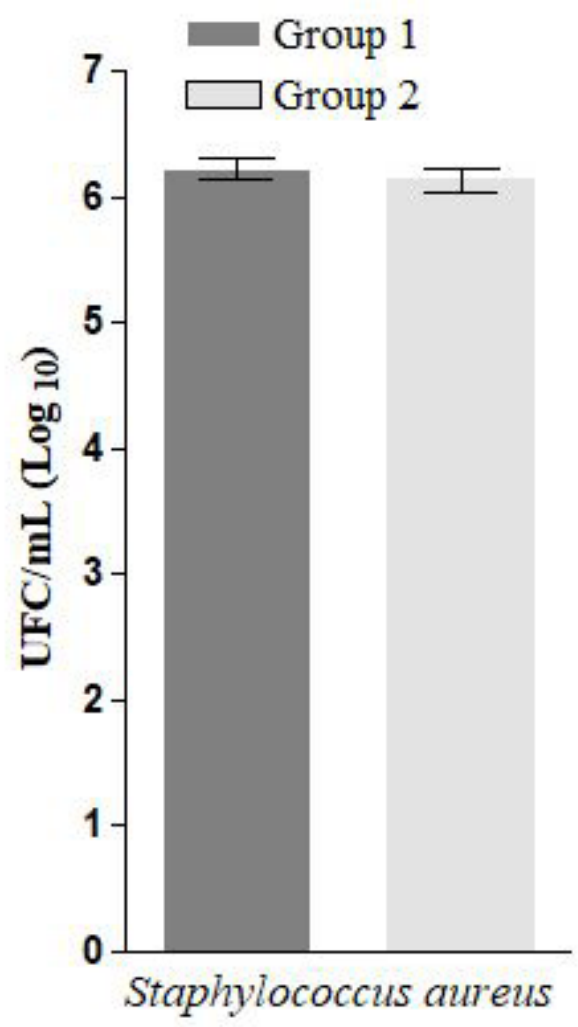

Figure 13. Quantification of proliferation on Group 1 - Nanotubes of $\mathrm{TiO}_{2}$ and Group 2 - Nanotubes of $\mathrm{TiO}_{2}$ covered with PCL after the S. aureus have been grown by incubated at $37^{\circ} \mathrm{C}$ for $48 \mathrm{~h}$. 


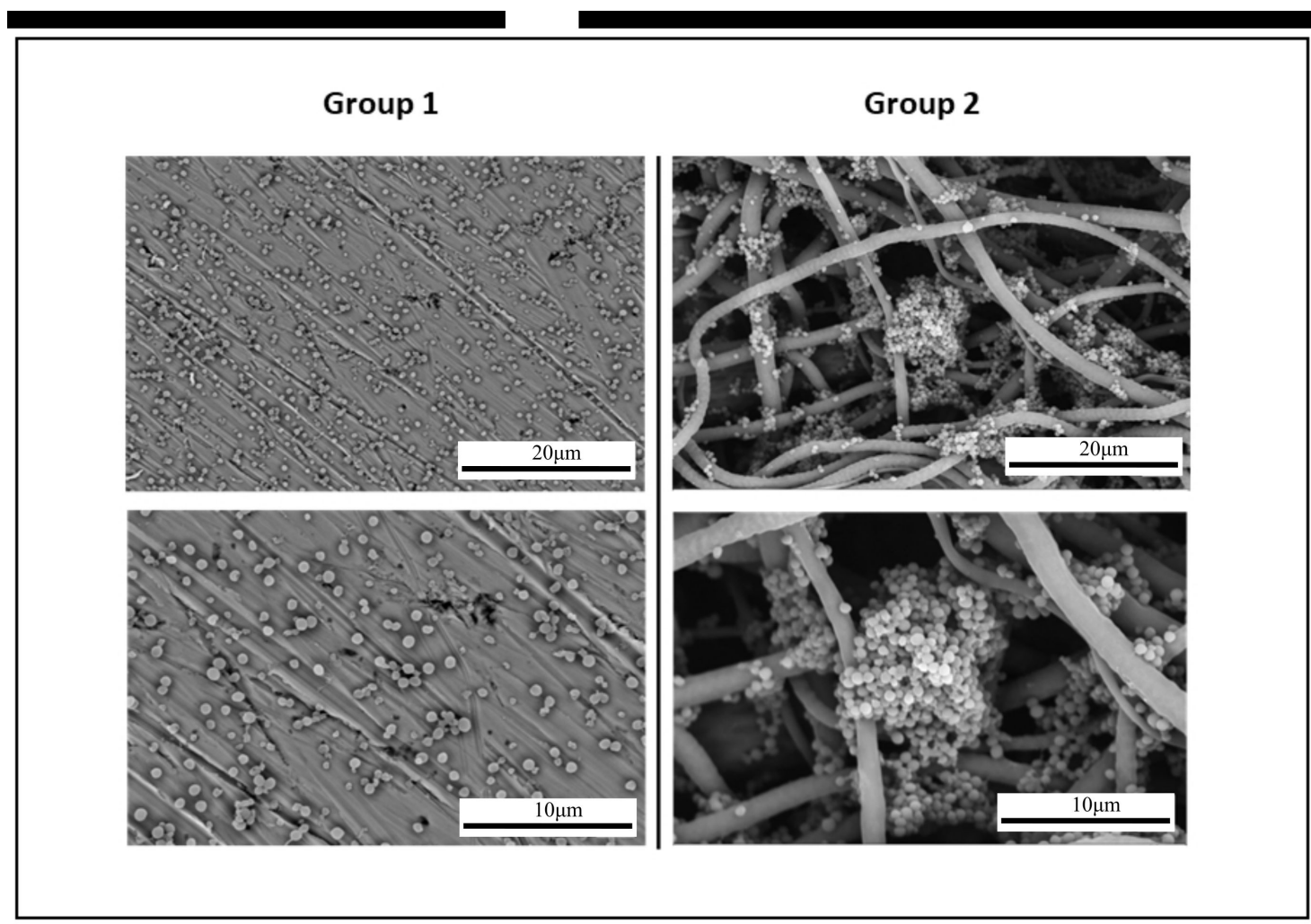

Figure 14. Representative SEM images of Group 1 - Nanotubes of $\mathrm{TiO}_{2}$ and Group 2 - Nanotubes of $\mathrm{TiO}_{2}$ covered with PCL after the $\mathrm{S}$. aureus have been grown by incubated at $37^{\circ} \mathrm{C}$ for $48 \mathrm{~h}$.

\section{Conclusion}

Recently, there has been an increased interest in exploring nanoscale surface topographies as biomimetic interfaces for implantable devices. In this study, the $\mathrm{TiO}_{2}$ nanotubes on the Ti-30Ta alloy surface were covered with PCL polymer to successfully provides nanoscale architectures. Microstructure features of the surface of the nanotubes $\mathrm{TiO}_{2}$ exhibited the anatase phase and peaks on PCL surface covered. The wettability properties show a hydrophilic interface on Group 1 and hydrophobic behavior on group 2. The adhesion and proliferation results indicate that Group 1 presented a significant effect on the number of cells present, showing an increase of cells from day 1 to day 7. Also, it was observed a slight increase of cell proliferation by Group 2 after 7 days. After 1 day, there was no significance cell proliferation between Group 1 and 2. However, the Group 1 presented higher cell proliferation than Group 2 at day 7. Also, both groups promoted high cell proliferation at day 7 . Cell viability revealed that cells proliferated and remained viable on Group 1 and 2 up to 7 days of culture. After 1, 4 and 7 days, it was not found statistically significant difference for Group 1 and 2. Cell morphology demonstrated that cells adhered and proliferated on these materials after 7 days in culture and cells were distributed on the surfaces. Both materials showed a favorable micro-environment for cells growth and proliferation which is a desire property for an implant. So, from the results it can conclude Group 1 and 2 are biocompatibility. In addition, the antimicrobial activity study presented both materials with similar growth of S. aureus.

Further studies are now directed towards to use PCL coatings on $\mathrm{TiO}_{2}$ nanotubes for drug release.

\section{Acknowledgements}

Partial funding support for this work was provided by the Brazilian federal government and the National Council for Scientific, Technological Development (CNPq) via Award Number 201271/2010-9, CNPq 486352/2013-7 and Fapesp 2014/14533-3.

\section{References}

1. Pandey A, Awasthi A, Saxena KK. Metallic implants with properties and latest production techniques: a review. Adv. Mater. Process. Technol. 2020;6(2):405-40.

2. Brånemark P-I, Engstrand P, Öhrnell L-O, Gröndahl K, Nilsson $\mathrm{P}$, Hagberg K, et al. Branemak novum: a new concept for rehabilitation of the edentulous mandible. preliminary results from a prospective clinical. Clin Implant Dent Relat Res. 1999;1(1):2-16.

3. Fan H, Guo Z. Bioinspired surfaces with wettability: biomolecule adhesion behaviors. Biomater Sci. 2020;8(6):1502-35.

4. Capellato P, Riedel NA, Williams JD, Machado JPB, Popat KC, Alves Claro APR. Ion bean etching on Ti-30Ta alloy for biomedical application. Mater Sci Forum. 2014;805:57-60.

5. Capellato P, Smith BS, Popat KC, Alves Claro AP. Cellular functionality on nanotubes of Ti-30Ta alloy. Materials Science Forum. 2015;805:61-4. 
6. Wang F, Li C, Zhang S, Liu H. Tantalum coated on titanium dioxide nanotubes by plasma spraying enhances cytocompatibility for dental implants. Surf Coat Tech. 2020;382:125161.

7. Capellato P, Silva G, Popat K, Simon-Walker R, Alves Claro AP, Zavaglia C. Cell investigation of Adult Human dermal fibroblasts on PCL nanofibers/TiO 2 nanotubes Ti-30Ta alloy for biomedical application. Artif. Organs. 2020:877-2.

8. Bayram C, Demirbilek M, Yalçin E, Bozkurt M, Doğan M, Denkbaş EB. Osteoblast response on co-modified titanium surfaces via anodization and electrospinning. Appl Surf Sci. 2014;288:143-8.

9. Fomby P, Cherlin AJ, Hadjizadeh A, Doillon CJ, Sueblinvong V, Weiss DJ, et al. Anodic oxide nanotube layers on Ti-Ta alloys: substrate composition, microstructure and self-organization on two-size scales. Corros Sci. 2006;12(14):181.

10. Madhurakkat Perikamana SK, Ahmad T, Lee S, Shin H. Frontiers in research for bone biomaterials. in Alghamdi H, Jansen J, editors. Dental implants and bone grafts: materials and biological issues. USA: Elsevier; 2020. p. 307-32.

11. Wei D, Zhou Y, Wang Y, Meng Q, Jia D. Structure and apatite formation of microarc oxidized $\mathrm{TiO} 2$-based films before and after alkali-treatment by various alkali concentrations. Surf Coat Tech. 2008;202(20):5012-9.

12. Souza MA, Carobolante JPA, Almeida RS, d'Ávila MA, Walker RS, Popat KC, et al. Immobilisation of apatite on Ti30Ta alloy surface by electrospinning of PCL. Surf Innov. 2017;5(2):68-74.

13. Wilson J. Metallic biomaterials: State of the art and new challenges. USA: Woodhead Publishing; 2018. p. 1-33.

14. Narushima T. New-generation metallic biomaterials. In: Niinomi M, editor. Metals for biomedical devices. USA: Woodhead Publishing; 2019.

15. Shimizu Y, Fujibayashi S, Yamaguchi S, Mori S, Kitagaki H, Shimizu T, et al. Bioactive effects of strontium loading on micro/ nano surface Ti6Al4V components fabricated by selective laser melting. Mater Sci Eng C Mater Biol Appl. 2020;109:110519.

16. Hintze V, Bierbaum S, Scharnweber D. Implant surface modifications and new development in surface coatings. In: Alghamdi H, Jansen J, editors. Dental implants and bone grafts: materials and biological issues. USA: Elsevier; 2019. p. 89-124.

17. Capellato P, Smith BS, Popat KC, Claro APRA. Fibroblast functionality on novel Ti30Ta nanotube array. Mater Sci Eng C. 2012;32(7):2060-7.

18. Pham QP, Sharma U, Mikos AG. Electrospinning of polymeric nanofibers for tissue engineering applications: a review. Tissue Eng. 2006;12(5):1197-211.

19. Stepanovska J, Matejka R, Rosina J, Bacakova L, Kolarova $H$. Treatments for enhancing the biocompatibility of titanium implants. Biomed Pap Med Fac Univ Palacky Olomouc Czech Repub. 2020;164(1):23-33.

20. Eduardo Muzzio N, Azzaroni O, Moya SE, Ángel Pasquale M. Concepts for Designing Tailored Thin Film Surfaces with Potential Biological Applications. In: Basu S, editor. Multilayer thin films: versatile applications for materials engineering. London: IntechOpen; 2020.

21. Hu T, Li Q, Dong H, Xiao W, Li L, Cao X. Patterning electrospun nanofibers via agarose hydrogel stamps to spatially coordinate cell orientation in microfluidic device. Small. 2017;13(3):1602610.

22. Teo WE, Ramakrishna S. Electrospun fibre bundle made of aligned nanofibres over two fixed points. Nanotechnology. 2005;16(9):1878-84.

23. Popat KC, Eltgroth M, LaTempa TJ, Grimes CA, Desai TA. Titania nanotubes: a novel platform for drug-eluting coatings for medical implants? Small. 2007;3(11):1878-81.

24. Smith BS, Yoriya S, Johnson T, Popat KC. Dermal fibroblast and epidermal keratinocyte functionality on titania nanotube arrays. Acta Biomater. 2011;7(6):2686-96.
25. Smith BS, Yoriya S, Grissom L, Grimes CA, Popat KC. Hemocompatibility of titania nanotube arrays. J Biomed Mater Res A. 2010;95(2):350-60.

26. Huang M-S, Wu C-Y, Ou K-L, Huang B-H, Chang T-H, Endo $\mathrm{K}$, et al. Preparation of a biofunctionalized surface on titanium for biomedical applications: surface properties, wettability variations, and biocompatibility characteristics. Appl Sci (Basel). 2020;10(4):1438.

27. Chaves JM, Escada ALA, Rodrigues AD, Alves Claro APR. Characterization of the structure, thermal stability and wettability of the TiO2 nanotubes growth on the Ti-7.5Mo alloy surface. Appl Surf Sci. 2016;370:76-82.

28. Popat KC, Mor G, Grimes CA, Desai TA. Surface modification of nanoporous alumina surfaces with poly(ethylene glycol). Langmuir. 2004;20(19):8035-41.

29. Warchomicka F. Surface topographies on the micro and nanoscale of metal alloys for tissue regeneration. In: Guarino V, Iafisco M, Spriano S, editors. Nanostructured biomaterials for regenerative medicine. USA: Elsevier; 2019. p. 315-36.

30. Kulkarni M, Patil-Sen Y, Junkar I, Kulkarni CV, Lorenzetti M, Iglič A. Wettability studies of topologically distinct titanium surfaces. Colloids Surf B Biointerfaces. 2015;129:47-53.

31. Zong X, Kim K, Fang D, Ran S, Hsiao BS, Chu B. Structure and process relationship of electrospun bioabsorbable nanofiber membranes. Polymer (Guildf). 2002;43(16):4403-12.

32. Guo S, He L, Yang R, Chen B, Xie X, Jiang B, et al. Enhanced effects of electrospun collagen-chitosan nanofiber membranes on guided bone regeneration. J Biomater Sci Polym Ed. 2020;31(2):155-68.

33. Ghasemi-Mobarakeh L, Prabhakaran MP, Morshed M, Nasr-Esfahani MH, Ramakrishna S. Bio-functionalized PCL nanofibrous scaffolds for nerve tissue engineering. Mater Sci Eng C. 2010;30(8):1129-36.

34. Ninago MD, Ciolino AE, Villar MA. Improvement in poly( $\varepsilon$ caprolactone) bio-activity. Structural characterization and in vitro assessment. Int. J. Polym. Mater. Polym. Biomater. 2020;69(4):201-10.

35. Mohammadinejad R, Kumar A, Ranjbar-Mohammadi M, Ashrafizadeh M, Han SS, Khang G, et al. Recent advances in natural gum-based biomaterials for tissue engineering and regenerative medicine: a review. Polymers (Basel). 2020;12(1):176.

36. Manam NS, Harun WSW, Shri DNA, Ghani SAC, Kurniawan $\mathrm{T}$, Ismail MH, et al. Study of corrosion in biocompatible metals for implants: a review. J Alloys Compd. 2017;701:698-715.

37. Hornschuh M, Zwicker P, Schmidt T, Kramer A, Müller G. In vitro evaluation of contact-active antibacterial efficacy of TiAl-V alloys coated with the antimicrobial agent PHMB. Acta Biomater. 2020;106:376-86.

38. Tamayo-Ramos JA, Rumbo C, Caso F, Rinaldi A, Garroni S, Notargiacomo A, et al. Analysis of polycaprolactone microfibers as biofilm carriers for biotechnologically relevant bacteria. ACS Appl Mater Interfaces. 2018;10(38):32773-81.

39. Chambers C, Stewart SB, Su B, Jenkinson HF, Sandy JR, Ireland AJ. Silver doped titanium dioxide nanoparticles as antimicrobial additives to dental polymers. Dent Mater. 2017;33(3):e115-23.

40. Song W, Ge S, Song W, Ge S. Application of antimicrobial nanoparticles in dentistry. Molecules. 2019;24(6):1033.

41. Almaguer-Flores A, Silva-Bermúdez P, Rodilc SE. Nanostructured biomaterials with antimicrobial activity for tissue engineering. In: Guarino V, Iafisco M, Spriano S, editors. Nanostructured biomaterials for regenerative medicine. USA: Elsevier; 2019. p. 81-137.

42. Besinis A, Hadi SD, Le HR, Tredwin C, Handy RD. Antibacterial activity and biofilm inhibition by surface modified titanium alloy medical implants following application of silver, titanium dioxide and hydroxyapatite nanocoatings. Nanotoxicology. 2017;11(3):327-38. 
43. Balouiri M, Sadiki M, Ibnsouda SK. Methods for in vitro evaluating antimicrobial activity: a review. J Pharm Anal. 2016;6(2):71-9.

44. Zhao L, Chu PK, Zhang Y, Wu Z. Antibacterial coatings on titanium implants. J Biomed Mater Res B Appl Biomater. 2009;91(1):470-80.

45. Pérez-Jorge C, Conde A, Arenas MA, Pérez-Tanoira R, Matykina E, de Damborenea JJ, et al. In vitro assessment of Staphylococcus epidermidis and Staphylococcus aureus adhesion on TiO2 nanotubes on Ti-6Al-4V alloy. J Biomed Mater Res A. 2012;100(7):1696-705.

46. Perez-Jorge C, Arenas MA, Conde A, Hernández-Lopez JM, de Damborenea JJ, Fisher S, et al. Bacterial and fungal biofilm formation on anodized titanium alloys with fluorine. J Mater Sci Mater Med. 2017;28(1):18.

47. Mohammed MT, Khan ZA, Siddiquee AN. Surface modifications of titanium materials for developing corrosion behavior in human body environment: a review. Procedia Mater. Sci. 2014;6:1610-8. 